\title{
Effect of Temperature on Spermatozoa Morphology
}

\author{
Khori Halimah $^{1}$, Ari Yuniastuti ${ }^{2}$, Sri Ratna Rahayu ${ }^{3}$ \\ $\left\{\right.$ khorihalimah5@gmail.com ${ }^{1}$, ari_yuniastuti@yahoo.co.id ${ }^{2}$, sriratnarahayu@mail.unnes.ac.id ${ }^{3}$ \} \\ Universitas Negeri Semarang, Semarang, Indonesia ${ }^{123}$
}

\begin{abstract}
Infertility is an important health and social problem. There are $15 \%$ of couples are infertile and $40 \%$ are infertile due to male infertility in the world. Temperature exposure is one of the determine factor in the normal percentage of spermatozoa morphology. This study generally aims to determine the effect of temperature exposure on spermatozoa morphology. Laboratory experimental research method was conducted by a post-test only control group design, carried out on 12 mice (Mus musculus). Mice were divided into 2 groups randomly, the control and treatment group with less and more than $35{ }^{\circ} \mathrm{C}(\mathrm{KK})$ temperature exposure consecutively in the UD Grinding Mill Berkah Tani (KP) rice mill for 35 days. The samples were terminated, spermatozoa were taken and preparations were made using gymsa painting on the $36^{\text {th }}$ day. The results showed there was a significant difference of spermatozoa morphology between control and treatment group $(p<0.05)$.
\end{abstract}

Keywords: temperature, morphology of spermatozoa, rice mill

\section{Introduction}

Infertility can be interpreted as the inability to reach conception in a one-year period for a partner, even though sexual intercourse without a condom is regular and adequate. A man is said to be infertile if he cannot impregnate his partner after one year of unprotected sexual intercourse. [1]. This is an important medical and social problem in the world, $15 \%$ of infertile couples and $40 \%$ are infertile due to male infertility [2]. Infertility has become an unpleasant problem, which is not only limited to these countries, but is also an incident worldwide. In the United Kingdom and the United States, it is estimated at $6 \%$ and $10 \%$, respectively. In Nigeria and parts of sub-Saharan Africa including the Republic of Sudan and Cameroon, the infertility rate can exceed $30 \%$ [3].

There are several main causes and risk factors for male infertility namely, environmental factors, lifestyle factors. Men with infertility will experience self-esteem gannguan and social inability, which in turn will cause a decrease in responsibility towards his wife and family [4]. Male infertility can be associated with sexual disorders in partners. Attention to psychological needs and rehabilitation in infertile couples can help them improve mental health and quality of life [5]. 
Today there is an increase in industrial activity in various countries [4]. Increased industrial activity resulted in an increase in temperature exposure [6]. Stress affects the work of the hypothalamus associated with GnRH secretion. GnRH levels affect the production of FSH and LH in the pituitary. Where LH will stimulate leydig cells to produce testorteron and FSH stimulate Sertoli cells to maintain the process of spermatogenesis in the testes. The mechanism of severe stress that affects the hormonal system is what influences fertility. Temperature of testis to produce healthy spermatozoa must be cold from the body's normal temperature, which is $35^{\circ} \mathrm{C}$. Increased temperature can also reduce the quality of the morphology of spermatozoa, resulting in decreased fertility that occurs in men. The results obtained show that $25^{\circ} \mathrm{C}$ has a high progressive movement of sperm and sperm viability compared to $4^{\circ} \mathrm{C}$ and $37^{\circ}$ C. Sperm stored at $25^{\circ} \mathrm{C}$ shows normal morphological structure while there are morphological changes in the temperature of $4^{\circ} \mathrm{C}$ and $37^{\circ} \mathrm{C}$ [6].

Based on the description above, research has been carried out on experimental animals in the laboratory by using tools as a source of temperature. Previous research has never been carried out directly in industrial workplaces, so it is necessary to study the effect of temperature exposure on workers exposed to temperature in their work. In the research to be carried out, the object of research is in the form of mice that are exposed to the temperature of a rice mill because it is difficult to get respondents who are willing to do spermatozoa examination.

\section{$2 \quad$ Method}

\subsection{The method of research}

The type of research to be conducted is an experimental study with the research design to be used is the Post Test Only Randomized Control Group Design.

\subsection{The population in this study}

The population in this study is mice (Mus musculus) with male sex which are kept in the biology laboratory of Darno Tikus Gunung Pati. The sample used in this study is 18 mice will be divided into two groups randomly. The number of samples used in the study was calculated using the WHO stipulation, namely the minimum number of experimental animals per group was 5, and added 1 tail to avoid the possibility of lost of follow, so that the total number of mice per group was 6 .

\subsection{The place of research}

The place of research was conducted at the UD Rice Mill. Berkah Tani, Pekalongan Regency. The activities were carried out in october 2019 until November 2019.

Sampling was carried out on the 36th day, mice in each group will be killed by the cervical dislokatio method. Then the sperm is taken by cutting the cauda epididymis until the ampulla vas deferens about $1.5-2 \mathrm{~cm}$ and then sorted by scapel and placed in a petri dish that has been filled with $0,25 \mathrm{cc}$ of physiological $\mathrm{NaCl} 0.86 \%$ 
solution that is 0.9 grams $\mathrm{NaCl}$ powder mixed with $100 \mathrm{ml}$ of aquabidest. In the process of taking it must be as fast as possible and immediately carried out morphological examination.

The validity and reliability test of the instrument in the form of the instrument will be calibrated at the Sultan Agung Islamic University Integrated Laboratory. All data obtained are then analyzed and seen whether or not normal data using the normality test using Shapiro Wilk and homogeneity testing with the Levene test. Followed by an unpaired $T$ test with a significance value $(\mathrm{p}<0.05)$. Statistical tests were performed with the SPSS program on a computer.

\section{$3 \quad$ Results and Materials}

\subsection{Results}

Observation of morphology of spermatozoa using a microscope with 1000x magnification using giemsa staining, which was assessed as spermatozoa with normal spermatozoa characteristics that have the shape of the head like a fishing hook and straight long tail, while abnormal sperm have irregular head shape, can be shaped like a banana, or irregular (amorphous), or too bent, and the tail is not straight or even has no tail, or there is only a tail without a head.

Data were tested for normality to find out the distribution of data evenly by using the Shapiro-Wilk test. Both groups showed that the initial data distribution was not normal but the data was transformed to obtain an average morphological percentage of spermatozoa in all groups with normal distribution with a $\mathrm{P}$ value $>0.05$. Then homogeneity test with Levene test was performed. Based on homogeneity test results obtained $\mathrm{P}$ value $<0.05$. This shows that the morphological data of spermatozoa in all groups was normal and homogeneous.

Because of the normal distribution of data and homogeneous data variations, an unpaired $\mathrm{T}$ test was obtained with a price of $\mathrm{p}<0.05$. The results showed that between the control group and the treatment group there were significant differences in the morphology of spermatozoa with a value of $p=0,000(p<0.05)$. This shows the temperature exposure for 35 days there is a difference. so as to prove there are differences in the morphology of spermatozoa with a lower morphological average, these results are in accordance with research conducted by [7]. 
Table 1. Morfology of Spermatozoa

\begin{tabular}{lll}
\hline Sample & Normal (\%) & Abnormal (\%) \\
\hline 1.1 & 92 & 8 \\
1.2 & $94 \ldots$ & 6 \\
1.3 & 96 & 4 \\
1.4 & 98 & 2 \\
1.5 & 98 & 2 \\
1.6 & 95 & 5 \\
1.7 & 90 & 8 \\
2.1 & 52 & 48 \\
2.2 & 58 & 42 \\
2.3 & 56 & 44 \\
2.4 & 64 & 36 \\
2.5 & 64 & 36 \\
2.6 & 60 & 40 \\
2.7 & 58 & 42 \\
\hline
\end{tabular}

\subsection{Materials}

Workers who are constantly exposed to noise and high temperatures will experience a state of stress that continues to increase [8]. Stress due to noise and temperature will stimulate the brain's Paraventricular Nucleus (PVN) to secrete Corticotrophin Releasing Hormone (CRH) and Arginine Vasopressin (AVP), where the hormone will increase the secretion of Adeno Corticotropin Hormone (ACTH) which will cause a decrease in hormone levels which is produced by the hypothalamus, Gonadotropin Realeasing Hormone $(\mathrm{GnRH})$. GnRH levels affect the production of FSH and LH in the pituitary. Where LH will stimulate leydig cells to produce testorteron and FSH stimulate Sertoli cells to maintain the process of spermatogenesis in the testes. LH serves to stimulate leyding cells to produce testosterone and maintain the morphology of testosterone to remain high in the testes. testosterone and FSH will work on the Sertoli cells will produce a variety of proteins, differentiation and cell metabolism that will maintain normal spermatogenesis [6].

The motility check is to find out whether there are abnormalities in the spermatozoa tail structure, if there are many immotile spermatozoa alive then there are abnormalities in the spermatozoa tail structure, especially in the flagellum structure. Meanwhile, testosterone and FSH will work on Sertoli cells will produce various proteins, differentiation and cell metabolism that will maintain normal spermatogenesis [6]. Where fertility in a man can be seen from the quality and quantity of normal spermatozoa which include sperm count, motility, morphology and ejaculate volume [9]. Stress due to noise will stimulate the brain's Paraventricular Nucleus (PVN) to secrete Corticotrophin Releasing Hormone (CRH) and Arginine Vasopressin (AVP), where the hormone will increase the secretion of Adeno Corticotropin Hormone $(\mathrm{ACTH})$ which will result in decreased hormone levels produced by the hypothala- 
mus, namely Gonadotropin Realeasing Hormone (GnRH). GnRH levels affect the production of FSH and LH in the pituitary. Where LH will stimulate leydig cells to produce testorteron and FSH stimulate Sertoli cells to maintain the process of spermatogenesis in the testes [10].

LH functions to stimulate leydig cells to produce testosterone and maintain the morphology of testosterone to remain high in the seminiferous tubules in the testis. Testosterone and FSH will work on the Sertoli cells will produce various proteins, differentiation and cell metabolism that will maintain normal spermatogenesis.

Hormonal system in the form of testosterone secretion, FSH and LH is what influences the formation of normal spermatozoa morphology. So that if there is a disruption in the production of the hormone spermatogenesis, the morphology of spermatozoa will be affected.

\section{Conclusions and Suggestions}

From the description of the results of the research that has been done, it can be concluded as follows: Obtained the effect of temperature on rice milling on spermatozoa morphology. There is a difference between the control group and the treatment group.

Acknowledgments Thank you to Dr. Rr.Sri Ratna Rahayu, M.Kes., Ph.D and Dr.Ari Yuniastuti, Spt., M.Kes, as supervisors who have provided direction and guidance for this study.

\section{References}

[1] Mahat, Roshan, K. etc. . "Biochemistry \& Analytical Biochemistry Risk Factors and Causes of Male Infertility.” Biochemistry \& Analytical Biochemistry, 2016,5(2): 1002-71.

[2] Mescher Mahat, Roshan, K. etc. "Biochemistry \& Analytical Biochemistry Risk Factors and Causes of Male Infertility." Biochemistry \& Analytical Biochemistry, 2016, 5(2): 1002-71.

[3] Sharma, Asha., "IMedPub Journals Male Infertility; Evidences, Risk Factors, Causes , Diagnosis and Management in Causes and Risk Factors of Infertility.” Annals Of Clinical and Laboratory Reserch, 2017,5(3): 1-10.

[4] Joja, O D, D Dinu, \& D Paun. "Psychological Aspects of Male Infertility. An Overview 1." Social and Behavioral Sciences 2015, 187: 359-63.

[5] Ghavi, Fatemeh, Leili M., Saeed A., \& Masomeh G. J.. "Male Infertility and Its Impact on Women's Sexual Behaviors: Need Attention to Psychological Problem as a Psychological Rehabilitation.” Iranian Rehabilitation Journal. 2017,15(2): 87-94.

[6] Adewoyin, Malik etc., "Male Infertility: The Effect of Natural Antioxidants and Phytocompounds on Se Mayowa al Oxidative Stress.” Disease, 2017,5(9): 1-26.

[7] Harrahap,I., Erris. "Pengaruh Kebisingan Terhadap Kuantitas Dan Kualitas Spermatozoa Tikus Putih (Rattus Norvegicus) Jantan Dewasa.” Media Litbangkes, 2014, 24 (3): 12328.

[8] Soom, Ann V. "Theriogenology Heat Stress Responses in Spermatozoa : Mechanisms and Consequences for Cattle Fertility.” Theriogenology Elsevier Journal, 2018, 113: 102-12. 
[9] Sukmaningsih, dkk. "Gangguan Spermatogenesis Setelah Pemberian Monosodium Glutamat Pada Mencit ( Mus Musculus L .) The Disturbance On Spermatogenesis After Administration Of Monosodium Glutamate On Mice ( Mus Musculus L .)." Jurnal Biologi,2009, (2): 49-52.

[10] Jalali, Maryam, \& Khodabakhsh K. (2012). "Effect of Noise Stress on Count , Progressive and Non- Progressive Sperm Motility, Body and Genital Organ Weights of Adult Male Rats.” Joundishapour University of Medical Science Journal, 2012 .5(1): 1-4 